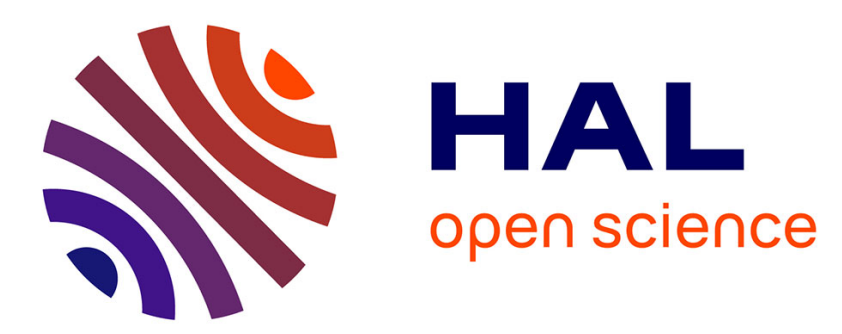

\title{
Absorption and biodegradation of toluene: Optimization of its initial concentration and the biodegradable non-aqueous phase liquid volume fraction
}

\author{
Imane Béchohra, Annabelle Couvert, Abdeltif Amrane
}

\section{- To cite this version:}

Imane Béchohra, Annabelle Couvert, Abdeltif Amrane. Absorption and biodegradation of toluene: Optimization of its initial concentration and the biodegradable non-aqueous phase liquid volume fraction. International Biodeterioration and Biodegradation, 2015, 104, pp.350-355. 10.1016/j.ibiod.2015.07.004 . hal-01188192

HAL Id: hal-01188192

https://hal-univ-rennes1.archives-ouvertes.fr/hal-01188192

Submitted on 3 Nov 2015

HAL is a multi-disciplinary open access archive for the deposit and dissemination of scientific research documents, whether they are published or not. The documents may come from teaching and research institutions in France or abroad, or from public or private research centers.
L'archive ouverte pluridisciplinaire HAL, est destinée au dépôt et à la diffusion de documents scientifiques de niveau recherche, publiés ou non, émanant des établissements d'enseignement et de recherche français ou étrangers, des laboratoires publics ou privés. 


\title{
Absorption and biodegradation of toluene: optimization of its initial concentration and the biodegradable non-aqueous phase liquid volume fraction
}

\author{
Imane Béchohra ${ }^{a, b, *}$, Annabelle Couvert ${ }^{a, b}$, Abdeltif Amrane Ab,c $^{a, b,}$ \\ ${ }^{a}$ Ecole Nationale Supérieure de chimie de Rennes, CNRS, UMR 6226, 11, Allée de \\ Beaulieu, CS 50837, 35708 Rennes Cedex 7, France. \\ ${ }^{b}$ Université Européenne de Bretagne, 5 Boulevard Laennec, Rennes, France. \\ ${ }^{c}$ Université de Rennes 1, CNRS, UMR 6226, 3 rue du Clos-Courtel, BP 90433, 35704 Rennes \\ Cedex 7, France \\ imane.bechohra@hotmail.fr, annabelle.couvert@ensc-rennes.fr,abdeltif.amrane@ensc- \\ rennes.fr.
}

*Corresponding author: ENSCR, Equipe CIP, UMR CNRS 6226 ISCR, 11 allée de Beaulieu, CS 50837, 35708 Rennes Cedex 7, France. Tel: 3322323 81 55, Fax: 33223238120 ; Email: imane.bechohra@hotmail.fr

\begin{abstract}
Di (2-EthylHexyl) Phthalate (DEHP) was selected as a biodegradable organic solvent to be implemented in a two-phase partitioning bioreactor (TPPB) dedicated to remove a model hydrophobic volatile organic compound (VOC), toluene. In a first step, the absorption capacity of toluene in the selected organic solvent was examined according to the partition coefficients H. In a second step, toluene biodegradation in DEHP by non-acclimated activated sludge was carried out for different volume fractions of DEHP in water and five different toluene concentrations $\left(4.3,43,106,212\right.$ and $\left.430 \mathrm{mg} \mathrm{l}^{-1}\right)$. Toluene showed high affinity for DEHP with $\mathrm{H}=0.99 \mathrm{~Pa} \cdot \mathrm{m}^{3} \cdot \mathrm{mole}^{-1}$. Both toluene and DEHP were completely consumed for $4.3 \mathrm{mg} \mathrm{l}^{-1}$ (initial toluene concentration) and a volume ratio of $0.1 \%$ DEHP in water. For an initial toluene concentration of $106 \mathrm{mg} \mathrm{l}^{-1}$ and a volume ratio of $0.1 \%$, total toluene consumption and $87 \%$ DEHP degradation yield were obtained after seven days of incubation.
\end{abstract}

Keywords : DEHP, biodegradation, activated sludge, VOC.

\section{Introduction}

Removal of volatile organic compounds (VOCs) like toluene is an important issue for human health, as well as for environment. Indeed, many of these compounds are toxic and considered as priority pollutants by the United States Environmental Protection Technology (US-EPA) (Ozturk and Yilmaz, 2006). Various technologies are available to perform their elimination: physical methods, like absorption, adsorption and condensation, and destructive methods, like incineration, catalytic treatment and biological treatment (Heymes et al., 2006; Kraakman et al., 2011). Recently, biological treatments of VOC have been extensively explored as an alternative to conventional methods, like incineration and catalytic treatment, according to the several advantages they offer in comparison to these conventional methods. Indeed, they do not produce any harmful by-products, are probably the most economical techniques for waste air treatment, and are also environment-friendly (Yeom and Daugulis, 2001a; Mudliar et al., 2010). Nevertheless, many VOC are hydrophobic and their removal in biological processes is limited 
by the difficulty to achieve substrate absorption in an aqueous phase, since microorganisms require water for their growth and hence pollutants transfer from gaseous polluted streams to an aqueous phase is needed (Collins and Daugulis, 1999).

In order to remove hydrophobic compounds such as toluene, benzene and xylene, a promising process consists in the coupling of absorption and biodegradation in a two-phase partitioning bioreactor (TPPB). To improve gas-liquid mass transfer of hydrophobic compounds, the absorbent is a Non-Aqueous Phase Liquid (NAPL) (Déziel et al., 1999; Darracq et al., 2012). Several results dealing with TPPBs are available in the literature (Yeom et al., 2000; Davidson and Daugulis, 2003; Aldric and Thonart, 2008; Quijano et al., 2009). The first step of TPPBs consists of VOC absorption in the NAPL and the second one concerns NAPL regeneration by VOC biodegradation. NAPL improves VOC absorption and at the same time decreases its toxicity towards microorganisms by lowering their concentration in the aqueous phase (Van Groenestijn and Lake, 1999; Tomei et al., 2010)

According to Abu Hamed et al., (2004) the most important criteria in the selection of a NAPL is its biocompatibility (absence of toxicity towards microorganisms), which can be estimated through its Log P value. According to Laane et al., (1987), solvents with a $\log \mathrm{P}$ greater than 4 are generally not toxic. However, NAPL can be attacked by microorganisms: for example (Darracq et al., 2009) found that DEHA was assimilated by activated sludge. Possible NAPL assimilation is especially undesired owing to their significant cost and hence their recycling is important in view of their reuse in a TPPB (Cesário et al., 1998; Darracq et al., 2010). Muñoz et al., (2007) considered that it is difficult to predict the stability of a given NAPL in the presence of microorganisms on long term, owing to a possible emergence of microorganisms able to degrade the NAPL.

In a previous study (Béchohra et al., 2014), another alternative was tested to overcome this technological lock; a biodegradable solvent (hexadecane) was used as a model solvent. In this case, the solvent should be biodegradable leading to its removal, concomitantly with the target VOC.

In the present work, toluene was chosen as hydrophobic VOC, due to its production in various industrial sectors : fuel, solvent and starting material for the production of plastics, paints, resins, pesticides and dyes (Yeom and Daugulis, 2001b). In view of its subsequent removal in a TPPB, its transfer in a liquid phase should be considered and for this purpose, the chosen solvent must be of low cost, not biodegradable by microorganisms and should have a good capacity to absorb the VOC (Daugulis and Boudreau, 2003). The solvent selected in this study was Di (2-EthylHexyl) Phthalate (DEHP). It is the most used plasticizer among the PVC products. It is considered as a hazardous substance for human health and hence is classified as Category II, by US-EPA, due to its toxicity towards reproduction and development (cancercausing chemicals classification criteria) (LaGrega et al., 1994). DEHP is released in large amounts in the environment (air, water and soil); the quantities issued are evaluated at 28,653 tons / year in Europe throughout its life cycle, i.e. from production to consumption, and finally as waste (Rank, 2005; Chao et al., 2015).

The aim of this work was therefore to study the biodegradation by activated sludge of the considered VOC in an emulsion of water/DEHP, simultaneously with the biodegradation of the selected organic solvent (DEHP). A particular attention was brought to the optimization of the ratio water/solvent. 


\section{Material and Methods}

\subsection{Microorganisms and media}

The biomass used in this work was activated sludge (AS) from Beaurade, the municipal wastewater treatment plant of Rennes (France). AS was washed four times with water to avoid any nutrients other than those contained in the culture media. The sludge was incubated in an 8 $\mathrm{L}$ lab-reactor. For growth and conservation, the activated sludge was cultivated under oxygen flow on the following mineral medium (2 g/day): Peptone, $0.64 \mathrm{~g} ; \mathrm{K}_{2} \mathrm{HPO}_{4}, 0.11 \mathrm{~g} ; \mathrm{NH}_{4} \mathrm{Cl}$, $15.2 \mathrm{~g} ; \mathrm{CH}_{3} \mathrm{COONa}, 140 \mathrm{~g}$ and some drops per month of Viandox (as an additional carbon source). Before use, activated sludge was washed several times with distillated water and diluted in a mineral salts medium containing (Chikh et al., 2011): $\mathrm{KH}_{2} \mathrm{PO}_{4}: 3.4 \mathrm{~g} \mathrm{l}^{-1} ; \mathrm{Na}_{2} \mathrm{HPO}_{4}$ : $3.09 \mathrm{~g} \mathrm{l}^{-1} ; \mathrm{NH}_{4} \mathrm{Cl}: 5 \mathrm{~g} \mathrm{l}^{-1} ; \mathrm{MgSO}_{4}: 0.12 \mathrm{~g} \mathrm{l}^{-1} ; \mathrm{CaCl}_{2}: 0.05 \mathrm{~g} \mathrm{l}^{-1} ; \mathrm{ZnSO}_{4}: 0.01 \mathrm{~g} \mathrm{l}^{-1} ; \mathrm{MnSO}_{4}: 0.01$ $\mathrm{g} \mathrm{l}^{-1} ; \mathrm{CuSO}_{4}: 0.003 \mathrm{~g} \mathrm{l}^{-1} ;\left(\mathrm{NH}_{4}\right)_{2} \mathrm{Fe}\left(\mathrm{SO}_{4}\right)_{2}: 0.1 \mathrm{~g} \mathrm{l}^{-1}$. The $\mathrm{pH}$ was adjusted to $7 \pm 0.2$.

\subsection{VOC and Solvents}

The selected VOC was toluene from Carbo Erba reagenti (Peypin, France) and the solvent used was DEHP $\left(\mathrm{MW}=390.60 \mathrm{~g} \mathrm{~mol}^{-1}, \mathrm{~d}=0.970, \mathrm{~T}_{\text {boiling }}=-50^{\circ} \mathrm{C}\right.$ ) from Acros organic (Geel, Belgium).

\subsection{Batch cultures}

Experiments were conducted in $250 \mathrm{ml}$ Erlenmeyer flasks closed with cellulosic caps to allow air exchange during the first set of experiments, and then with glass caps equipped with two sampling points sealed with Teflon septum allowing needle introduction. To sample the gaseous phase, a microsyringe with a capacity of $500 \mu \mathrm{l}$ was used and the sample was injected directly in the gaseous chromatography (GC); aqueous samples were stored in closed vials for further analysis of by-products. The Erlenmeyer headspace was $50 \mathrm{ml}$. For each experiment, a given number of identical $250 \mathrm{ml}$ Erlenmeyer flasks were considered. Initially a concentration of 4.3 $\mathrm{g}$ of toluene per liter of DEHP was tested for four volume ratios DEHP in water: 5\%, 2\%, 0.5\% and $0.1 \%$. Each series of experiments consisted of 13 flasks containing $0.5 \mathrm{~g} \mathrm{l}^{-1}$ of activated sludge and nutrients as indicated above (see microorganisms and media). A blank test containing the considered amount of DEHP was also carried out to determine the fraction of VOC lost by possible leaks or adsorption on the cellulosic stoppers; its composition was the same as the other flasks except for nutrients and biomass. Stirring was set at $300 \mathrm{rpm}$ and flasks were placed in a thermostated oven $\left(\mathrm{T}=25^{\circ} \mathrm{C}\right)$. Because of the biodegradability and the negligible solubility of DEHP in the aqueous phase, it was not possible to perform a homogenous sampling of the two-phase system and hence a sacrificial method was considered, at pre-determined time intervals, duplicate Erlenmeyers were taken for analysis. Gaseous sample was analyzed to quantify the remaining toluene quantity.

\subsection{Analytical Methods}

The toluene concentration in the gas phase was measured by gas chromatography (GC) coupled with a flame ionization detector from Thermo scientific (California, United States). Metabolites formed in the aqueous phase were identified by gas chromatography coupled with mass spectrometry (MS) with headspace (HS) from Perkin Elmer (California, United States). For the quantification of DEHP degradation, an extraction by hexane $(25 \% \mathrm{v} / \mathrm{v})$ coupled to $10 \mathrm{~min}$ ultrasonication was performed. The extract was then analyzed by gas chromatography coupled with a flame ionization detector from Perkin Elmer. The analytical conditions are reported in 
Table 1 and were selected according to the related literature (Chikh et al., 2011; de Moura Carrara et al., 2011).

The toluene partition coefficient in each of the different phases was measured by the static method, by introducing a known amount of toluene in $22 \mathrm{ml}$ vials sealed, having introduced the organic solvent or the emulsion in advance. Then the system was subjected to a fixed rotary shaking at a constant temperature of $25^{\circ} \mathrm{C}$.

The equilibrium was reached after 48 hours; toluene concentration in the gas phase was quantified by gas phase chromatography (table 1). According to the mass balance, toluene concentration in the aqueous phase was then deduced. Then, the dimensionless Henry's constant $(\mathrm{H})$ and Henry's constant $\left(\mathrm{H}^{\prime}\right)$ could be calculated by Equations (1) and (2) respectively:

$$
\mathrm{H} \mathrm{C}_{\mathrm{L}}=\mathrm{C}_{\mathrm{G}}
$$

$$
\mathrm{H}^{\prime}=\mathrm{H} \mathrm{R} \mathrm{T}
$$

$\mathrm{R}$ and $\mathrm{T}$ are the constant of perfect gas and the working temperature respectively.

The total amount of toluene $\mathrm{m}_{\mathrm{t}}$ was then deduced from the mass balance (Equation 3):

$$
\mathrm{m}_{\mathrm{t}}=\mathrm{m}_{\mathrm{tg}}+\mathrm{m}_{\mathrm{te}}
$$

$\mathrm{m}_{\mathrm{tg}}, \mathrm{m}_{\mathrm{te}}$ were the toluene mass in the gas phase and in the emulsion (DEHP in water) respectively at a given time $t ; \mathrm{m}_{\mathrm{tL}}$ the toluene mass lost was deduced from the blank test between the initial time and a given time $t$ :

$$
m_{t L}=\left(m_{0 g b}+m_{0 e b}\right)-\left(m_{t g b}+m_{t e b}\right)
$$

$\mathrm{m}_{0 \mathrm{gb}}, \mathrm{m}_{0 \mathrm{eb}}$ were the toluene masses of the blank test in the gas phase and the emulsion at initial time and $\mathrm{m}_{\mathrm{tgb}}, \mathrm{m}_{\mathrm{teb}}$ were the toluene masses of the blank test at a given time $\mathrm{t}$ in the gaseous phase and the emulsion.

Toluene concentration in the emulsion at a given time $t$ in the gas phase and in the blank test can be then deduced from the partition coefficient $\mathrm{H}$ for different volume fractions and from the toluene concentration in the gaseous phase at a given time $\mathrm{t}$ (Eq. 5):

$$
\mathrm{C}_{\mathrm{e}}=\mathrm{C}_{\mathrm{G}} / \mathrm{H}
$$

The biomass growth was quantified by means of turbidimetric measurements at $600 \mathrm{~nm}$ which were related to dry matter (DM) through a calibration curve.

The experiments were performed in duplicate; the mean values with the corresponding error were reported in the figures.

\section{Results and discussion}

\subsection{Partition coefficient}

Figure 1 shows the toluene concentration in the gas phase $\left(\mathrm{mg} \mathrm{l}^{-1}\right)$ as a function of the toluene concentration in the liquid phase $\left(\mathrm{mg} \mathrm{l}^{-1}\right)$ when equilibrium was reached. To model experimental points, straight lines were used with correlation coefficients $\left(\mathrm{R}^{2}\right)$ greater than 0.99 , confirming the accuracy of the method. The adimensionless Henry's constant $\mathrm{H}$, corresponded to the slope of the straight lines (Eq. 1). The value (H') obtained for pure DEHP was 0.99 Pa. $\mathrm{m}^{3} \cdot \mathrm{mole}^{-1}$. As a comparison, the value of the toluene partition coefficient in silicone oil 
(PDMS, $5 \mathrm{cP}$ viscosity) and hexadecane given in the literature were 1.6 and $2.50 \mathrm{~Pa} \cdot \mathrm{m}^{3} \cdot \mathrm{mole}^{-1}$, respectively (Vuong et al., 2009; Darracq et al., 2010). Several volume ratios of DEHP in water were tested $(5 \%, 2 \%, 0.5 \%$ and $0.1 \%)$. As expected, the partition coefficient increased for decreasing ratios (Table 2 ).

Even for a volume ratio of $0.1 \%, \mathrm{H}$ was significantly lower than that of water, since a value of $247.76 \pm 10.23$ Pa.m ${ }^{3}$. mole $^{-1}$ was obtained, which should be compared to that of water, 652 Pa.m ${ }^{3} \cdot$ mole $^{-1}$ (Robbins et al., 1993); it is however less attractive than a ratio close to $2 \%$.

\subsection{Biodegradation kinetics}

\subsubsection{Influence of the DEHP volume fraction}

Time-courses of the toluene amount in the gas phase for the four volume ratios of DEHP in water tested are shown in Figure 2a. Experiments were carried out for an initial toluene concentration in DEHP of $4.3 \mathrm{~g} \mathrm{l}^{-1}$. For all volume ratios, the toluene amount decreased over time, indicating its consumption by the activated sludge. The decrease of the $\mathrm{pH}$ confirmed the bacterial activity (about $0.5 \mathrm{pH}$ unit less per day). Less than four days were necessary for activated sludge to remove toluene in the DEHP whatever the DEHP-to-water ratio. As expected, the time needed for total toluene consumption decreased with the volume ratio, indicating a lower degradation time when the volume ratio decreased, since the initial toluene concentration in DEHP was maintained constant. Figure $2 \mathrm{~b}$ shows the total toluene amount deduced from the mass balance (Eq. 3), taking the toluene losses during the assays into account. The whole amount of toluene initially introduced was not totally degraded since some toluene was lost due to gas leaks through caps and / or adsorption on caps (Darracq et al., 2009). The toluene degradation rate in 5\% DEHP was $9.56 \mathrm{mg} \mathrm{l}^{-1} \cdot \mathrm{d}^{-1}$, higher than the value found in a previous study with hexadecane, namely $5.78 \mathrm{mg} \mathrm{l}^{-1} . \mathrm{d}^{-1}$ (Béchohra et al., 2014).

The degradation rate decreased with the volume ratio leading to a significant percentage of leaks, especially in the case of the ratio of $0.1 \%$ (90\% of losses). Indeed, for a low volume ratio, bioavailability is limited by stripping and hence no adapted biomass can develop in the system (Mozo et al., 2012). To reduce the leaks, a test was carried out with Erlenmeyer flasks closed by glass caps for the ratio of $0.1 \%$, leading to a significant reduction of the leaks, $29 \%$.

DEHP biodegradation was also examined for the four DEHP/water volume ratios considered (Figure 3). For a ratio of 5\%, a lag time of 3 to 4 days was observed, followed by a decrease of the DEHP amount over time; the degradation yield reached $21 \%$ after seven days, which was quite low in comparison with the targeted objective. Nonetheless, (Chang et al., 2004) found that the degradation of eight phthalate esters (among them DEHP) is delayed by the addition of an aromatic hydrocarbon, nonylphenol. The presence of toluene could therefore slow the DEHP biodegradation, indicating a preference of the activated sludge for toluene over DEHP. Previous studies on phthalate esters also suggested that the length of the alkyl chain affects biodegradation. Short chain phthalate esters would be more biodegradable than long chain phthalate esters such as DEHP (Boonnorat et al., 2014).

For the ratio of $2 \%$, there was no noticeable lag time; however, a similar and low DEHP degradation was observed (21\%). A pH decrease was also noted (0.5 unit per day), as well as a bacterial growth, from $0.5 \mathrm{~g}_{\mathrm{MS}} \mathrm{l}^{-1}$ to 2.7 and $2.1 \mathrm{~g}_{\mathrm{MS}} \mathrm{l}^{-1}$ for the ratios of 5 and $2 \%$, respectively, proofs of biological activity (Results not shown) 
When the ratio was reduced to $0.5 \%$, the DEHP degradation was faster and the yield reached $46.7 \%$ after 7 days. Finally, for a very low ratio (0.1\%), the DEHP amount decreased over time until a final mass of $0.018 \mathrm{~g}$, corresponding to a degradation yield of $92.4 \%$, i.e. an almost total consumption of DEHP by microorganisms after 7 days. Some authors also achieved a complete DEHP biodegradation for an initial solvent concentration of $0.75 \mathrm{~g}^{-1}$ (corresponding to $0.08 \%$ DEHP/water volume ratio) in just 40 hours, but using pure Gordonia sp. (Sarkar et al., 2013).

To conclude, concomitant biodegradation of toluene and DEHP showed good results when the DEHP-to-water volume ratio was $0.1 \%$ in the presence of activated sludge.

\subsubsection{Degradation of $0.1 \%$ DEHP in water}

A new series of experiments was carried out in bottles closed with glass caps to minimize leakages. The variations of the total toluene amount for initial concentrations ranging between 43 and $430 \mathrm{mg} \mathrm{l}^{-1}$ are shown in Figure 4. For the high concentrations, 212 and $430 \mathrm{mg} \mathrm{l}^{-1}$, no decrease of the toluene amount was observed within 7 days; although an increase in dry matter was observed for both concentrations (Figure 5), suggesting a preference of the microorganisms for DEHP over toluene (Figure 6) and/or most likely due to a toxicity of toluene at high concentrations. In fact, (Hino et al., 1994), who investigated the degradation of two carbon substrates, glucose and lactate by a bacterial strain, Megasphaera elsdenii, found that surprisingly the strain shows a preference for lactate over glucose. Besides, (Bordel et al., 2007) highlighted a decrease of the specific growth rate of Pseudomonas putida for a toluene concentration of $250 \mathrm{mg} \mathrm{l}^{-1}$. It was also reported that the lowest toluene concentration that inhibits Burkholderia cepacia species is $155 \mathrm{mg} \mathrm{l}^{-1}$ (Alagappan and Cowan, 2003).

At low initial toluene concentrations, 106 and $43 \mathrm{mg} \mathrm{l}^{-1}$, after 48 hours lag time, the toluene quantity decreased until reaching a yield of $60 \%$, taking into account that the rest of the toluene corresponded to the leaks. This proved that a toluene concentration of $106 \mathrm{mg} \mathrm{l}^{-1}$ was not inhibitory for activated sludge and can be totally biodegraded, as for an initial toluene concentration of $43 \mathrm{mg} \mathrm{l}^{-1}$.

Figure 6 shows the variations of DEHP amount with time, for initial toluene concentrations in the range 43 to $430 \mathrm{mg} \mathrm{l}^{-1}$. For low toluene concentrations the DEHP amount decreased at the beginning of the experience, and then reached a constant value between the $2^{\text {nd }}$ and the $5^{\text {th }}$ day. This latter phase may be due either to the presence of biodegradation by-products, including 2ethylhexanol and octanal, or to the impoverishment of the culture medium in dissolved oxygen. Indeed, according to (Magdouli et al., 2013), under aerobic conditions, more than a week or a month are necessary for DEHP biodegradation, while in anaerobic conditions, the DEHP halflife time exceeds one month. DEHP biodegradation was then observed beyond the $5^{\text {th }}$ day, which would show an acclimation of microorganisms to toxic by-products, or to the absence of oxygen. Figure 5 shows that the biodegradation obtained after 7 days culture reached 68.9 and $87.0 \%$ for initial toluene concentrations of 43 and $106 \mathrm{mg} \mathrm{l}^{-1}$.

For toluene concentrations of $430 \mathrm{mg} \mathrm{l}^{-1}$ and $212 \mathrm{mg} \mathrm{l}^{-1}$, there was a significant decrease of the DEHP amount during the first 24 hours, which coincided with a significant growth of activated sludge (Figure. 5). Beyond 4 days of culture, dry matter and DEHP concentration remained constant. This may be due to the presence of 2-ethylhexanol and 2-ethylhexanal, which were the DEHP degradation by-products detected by GC/MS, but also to an inhibitory effect of toluene at these high concentrations, as shown above (Figure. 4). Oxygen depletion cannot be questioned, since for the same DEHP amount and using glass caps, DEHP degradation reached $69 \%$ for the initial toluene concentration of $43 \mathrm{mg} \mathrm{l}^{-1}$. 


\section{Conclusions}

DEHP was investigated as a possible weak added-value solvent. The experiments carried out in Erlenmeyer flasks allowed to choose a DEHP-to-water volume ratio of $0.1 \%$, which shows interesting results in comparison to other volume ratios $(5,2$ and $0.5 \%)$. Indeed, high DEHP biodegradation was observed after 7 days, up to a degradation yield of $83 \%$, without acclimation of activated sludge. However, gas toluene losses due to leakage remain a problem to solve. An alternative solution was to close the flasks with glass caps instead of cellulose caps. Thereafter, different initial toluene concentrations were tested in flasks. A toluene concentration of $106 \mathrm{mg}$ $1^{-1}$ showed the highest degradation yields for both toluene and DEHP. Beyond twice this concentration (212 $\left.\mathrm{mg} \mathrm{l}^{-1}\right)$, the toluene was not removed, showing the limits of the system.

\section{References}

Abu Hamed, T., Bayraktar, E., Mehmetoğlu, Ü., Mehmetoğlu, T., 2004. The biodegradation of benzene, toluene and phenol in a two-phase system. Biochem. Eng. J. 19, 137-146. doi:10.1016/j.bej.2003.12.008

Alagappan, G., Cowan, R., 2003. Substrate inhibition kinetics for toluene and benzene degrading pure cultures and a method for collection and analysis of respirometric data for strongly inhibited cultures. Biotechnol. Bioeng. 83, 798-809. doi:10.1002/bit.10729

Aldric, J.-M., Thonart, P., 2008. Performance evaluation of a water/silicone oil two-phase partitioning bioreactor using Rhodococcus erythropolis T902.1 to remove volatile organic compounds from gaseous effluents. J. Chem. Technol. Biotechnol. 83, 1401-1408. doi:10.1002/jctb.1956

Béchohra, I., Couvert, A., Amrane, A., 2014. Biodegradation of toluene in a two-phase partitioning bioreactor - impact of activated sludge acclimation. Environ. Technol. 35, 735-740. doi:10.1080/09593330.2013.848938

Boonnorat, J., Chiemchaisri, C., Chiemchaisri, W., Yamamoto, K., 2014. Microbial adaptation to biodegrade toxic organic micro-pollutants in membrane bioreactor using different sludge sources. Bioresour. Technol., Special Issue: CESE 2013 \& Special Issue: ICABB 2013 165, 50-59. doi:10.1016/j.biortech.2014.04.024

Bordel, S., Muñoz, R., Díaz, L.F., Villaverde, S., 2007. New insights on toluene biodegradation by Pseudomonas putida F1: influence of pollutant concentration and excreted metabolites. Appl. Microbiol. Biotechnol. 74, 857-866. doi:10.1007/s00253-006-0724-8

Cesário, M.T., Brandsma, J.B., Boon, M.A., Tramper, J., Beeftink, H.H., 1998. Ethene removal from gas by recycling a water-immiscible solvent through a packed absorber and a bioreactor. J. Biotechnol. 62, 105-118. doi:10.1016/S0168-1656(98)00052-2

Chang, B.V., Yang, C.M., Cheng, C.H., Yuan, S.Y., 2004. Biodegradation of phthalate esters by two bacteria strains. Chemosphere 55, 533-538. doi:10.1016/j.chemosphere.2003.11.057

Chao, K.-P., Huang, C.-S., Wei, C.-Y., 2015. Health risk assessments of DEHP released from chemical protective gloves. J. Hazard. Mater. 283, 53-59. doi:10.1016/j.jhazmat.2014.09.010 
Chikh, R., Couvert, A., Aït Amar, H., Amrane, A., 2011. Toluene biodegradation in a two phase partitioning system-Use of a biodegradable solvent. Environ. Prog. Sustain. Energy 30, 303-308. doi:10.1002/ep.10477

Collins, L.D., Daugulis, A.J., 1999. Benzene/toluene/p-xylene degradation. Part I. Solvent selection and toluene degradation in a two-phase partitioning bioreactor. Appl. Microbiol. Biotechnol. 52, 354-359.

Darracq, G., Couvert, A., Couriol, C., Amrane, A., Cloirec, P.L., 2012. Removal of Hydrophobic Volatile Organic Compounds in an Integrated Process Coupling Absorption and BiodegradationSelection of an Organic Liquid Phase. Water. Air. Soil Pollut. 223, 4969-4997. doi:10.1007/s11270012-1251-0

Darracq, G., Couvert, A., Couriol, C., Amrane, A., Le Cloirec, P., 2010. Kinetics of toluene and sulfur compounds removal by means of an integrated process involving the coupling of absorption and biodegradation. J. Chem. Technol. Biotechnol. 85, 1156-1161. doi:10.1002/jctb.2414

Darracq, G., Couvert, A., Couriol, C., Amrane, A., Le Cloirec, P., 2009. Absorption and biodegradation of hydrophobic volatile organic compounds: determination of Henry's constants and biodegradation levels. Water Sci. Technol. 59, 1315. doi:10.2166/wst.2009.124

Daugulis, A.J., Boudreau, N.G., 2003. Removal and destruction of high concentrations of gaseous toluene in a two-phase partitioning bioreactor by Alcaligenes xylosoxidans. Biotechnol. Lett. 25, 14211424.

Davidson, C.T., Daugulis, A.J., 2003. Addressing biofilter limitations: A two-phase partitioning bioreactor process for the treatment of benzene and toluene contaminated gas streams. Biodegradation 14, 415-421. doi:10.1023/A:1027363526518

De Moura Carrara, S.M.C., Morita, D.M., Boscov, M.E.G., 2011. Biodegradation of di(2ethylhexyl)phthalate in a typical tropical soil. J. Hazard. Mater. 197, 40-48. doi:10.1016/j.jhazmat.2011.09.058

Déziel, E., Comeau, Y., Villemur, R., 1999. Two-liquid-phase bioreactors for enhanced degradation of hydrophobic/toxic compounds. Biodegradation 10, 219-233.

Heymes, F., Manno-Demoustier, P., Charbit, F., Fanlo, J.L., Moulin, P., 2006. A new efficient absorption liquid to treat exhaust air loaded with toluene. Chem. Eng. J. 115, 225-231. doi:10.1016/j.cej.2005.10.011

Hino, T., Shimada, K., Maruyama, T., 1994. Substrate preference in a strain of Megasphaera elsdenii, a ruminal bacterium, and its implications in propionate production and growth competition. Appl. Environ. Microbiol. 60, 1827-1831.

Kraakman, N.J.R., Rocha-Rios, J., Loosdrecht, M.C.M. van, 2011. Review of mass transfer aspects for biological gas treatment. Appl. Microbiol. Biotechnol. 91, 873-886. doi:10.1007/s00253-011-3365-5

Laane, C., Boeren, S., Vos, K., Veeger, C., 1987. Rules for optimization of biocatalysis in organic solvents. Biotechnol. Bioeng. 30, 81-87. doi:10.1002/bit.260300112 
LaGrega, M.D., Buckingham, P.L., Evans, J.C., 1994. Hazardous waste management. McGraw-Hill, New York.

Magdouli, S., Daghrir, R., Brar, S.K., Drogui, P., Tyagi, R.D., 2013. Di 2-ethylhexylphtalate in the aquatic and terrestrial environment: A critical review. J. Environ. Manage. 127, 36-49. doi:10.1016/j.jenvman.2013.04.013

Mozo, I., Lesage, G., Yin, J., Bessiere, Y., Barna, L., Sperandio, M., 2012. Dynamic modeling of biodegradation and volatilization of hazardous aromatic substances in aerobic bioreactor. Water Res. 46, 5327-5342. doi:10.1016/j.watres.2012.07.014

Mudliar, S., Giri, B., Padoley, K., Satpute, D., Dixit, R., Bhatt, P., Pandey, R., Juwarkar, A., Vaidya, A., 2010. Bioreactors for treatment of VOCs and odours - A review. J. Environ. Manage. 91, 10391054. doi:10.1016/j.jenvman.2010.01.006

Muñoz, R., Villaverde, S., Guieysse, B., Revah, S., 2007. Two-phase partitioning bioreactors for treatment of volatile organic compounds. Biotechnol. Adv. 25, 410-422.

Ozturk, B., Yilmaz, D., 2006. Absorptive Removal of Volatile Organic Compounds from Flue Gas Streams. Process Saf. Environ. Prot. 84, 391-398. doi:10.1205/psep05003

Quijano, G., Hernandez, M., Thalasso, F., Muñoz, R., Villaverde, S., 2009. Two-phase partitioning bioreactors in environmental biotechnology. Appl. Microbiol. Biotechnol. 84, 829-846. doi:10.1007/s00253-009-2158-6

Rank, J., 2005. Classification and risk assessment of chemicals: the case of DEHP in the light of REACH. J. Transdiscipl. Environ. Stud. 4.

Robbins, G.A., Wang, S., Stuart, J.D., 1993. Using the static headspace method to determine Henry's law constants. Anal. Chem. 65, 3113-3118. doi:10.1021/ac00069a026

Sarkar, J., Chowdhury, P.P., Dutta, T.K., 2013. Complete degradation of di-n-octyl phthalate by Gordonia sp. strain Dop5. Chemosphere 90, 2571-2577. doi:10.1016/j.chemosphere.2012.10.101

Tomei, M.C., Annesini, M.C., Rita, S., Daugulis, A.J., 2010. Two-phase partitioning bioreactors operating with polymers applied to the removal of substituted phenols. Environ. Sci. Technol. 44, 72547259.

Van Groenestijn, J.W., Lake, M.E., 1999. Elimination of alkanes from off-gases using biotrickling filters containing two liquid phases. Environ. Prog. 18, 151-155. doi:10.1002/ep.670180310

Vuong, M.-D., Couvert, A., Couriol, C., Amrane, A., Le Cloirec, P., Renner, C., 2009. Determination of the Henry's constant and the mass transfer rate of VOCs in solvents. Chem. Eng. J. 150, 426-430. doi:10.1016/j.cej.2009.01.027

Yeom, S.-H., Dalm, M.C.F., Daugulis, A.J., 2000. Treatment of high-concentration gaseous benzene streams using a novel bioreactor system. Biotechnol. Lett. 22, 1747-1751. doi:10.1023/A:1005689917744 
Yeom, S.-H., Daugulis, A.J., 2001a. Benzene degradation in a two-phase partitioning bioreactor by<i> Alcaligenes xylosoxidans $</ \mathrm{i}>$ Y234. Process Biochem. 36, 765-772.

Yeom, S.-H., Daugulis, A.J., 2001b. Development of a novel bioreactor system for treatment of gaseous benzene. Biotechnol. Bioeng. 72, 156-165. 


\section{Figure captions}

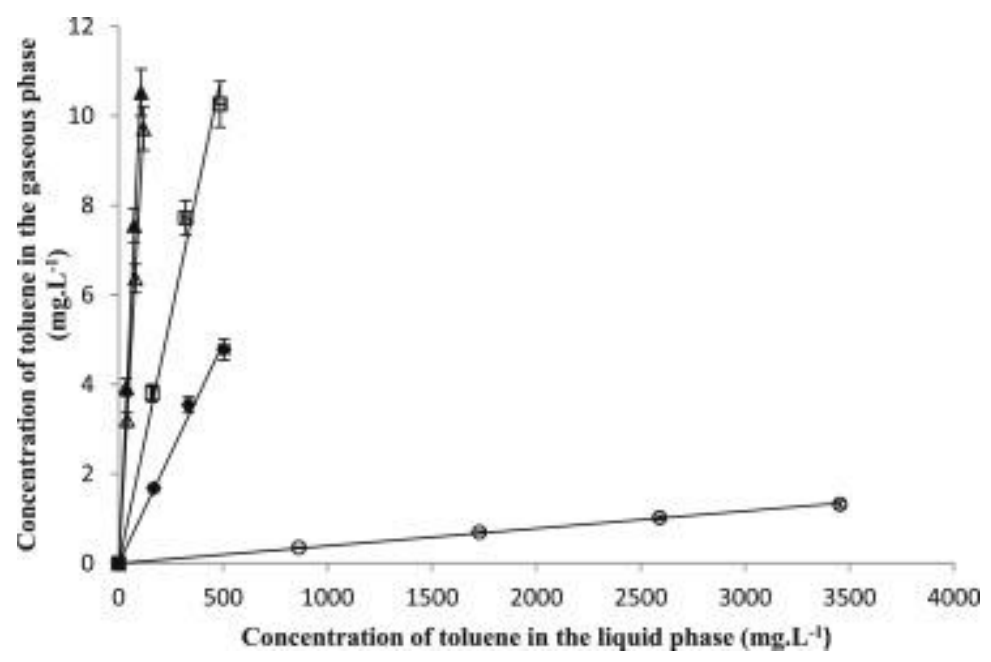

Figure.1. Determination of the partition coefficient $(H)$ for different volume fractions of DEHP in water
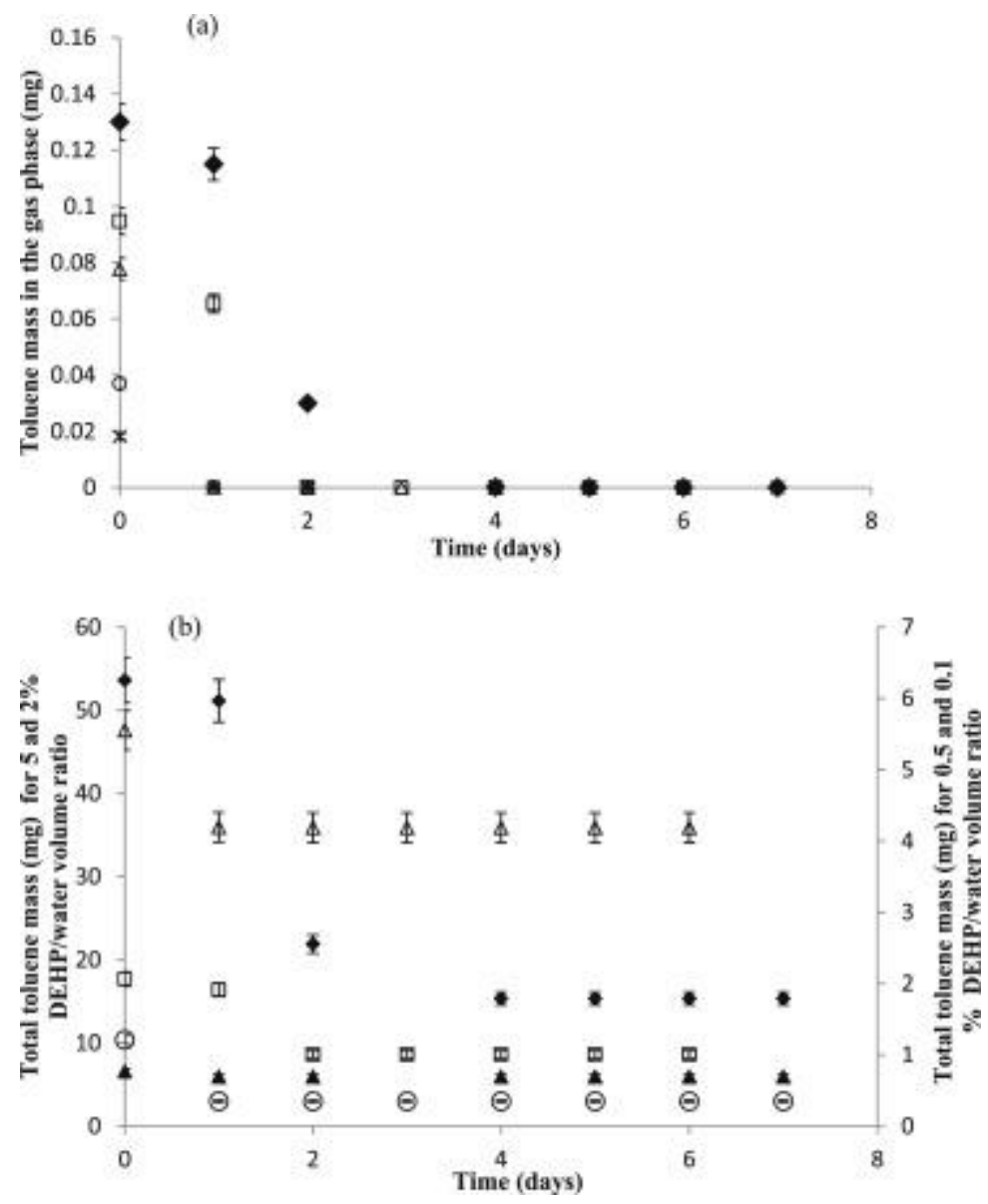

Figure.2. Time-course of toluene amount in the gas phase (a) and its total amount (b) during biodegradation by activated sludge in batch culture for an initial toluene concentration in DEHP of $4.3 \mathrm{~g} / \mathrm{L}, \mathrm{pH}=7, \mathrm{~T}=25^{\circ} \mathrm{C}$, stirring rate $=300 \mathrm{rpm}$.

$\checkmark 5 \% \quad \square 2 \% \quad \triangle 0.5 \% \quad \Delta 0.1 \% \quad \bigcirc 0.1 \%$ glass caps 


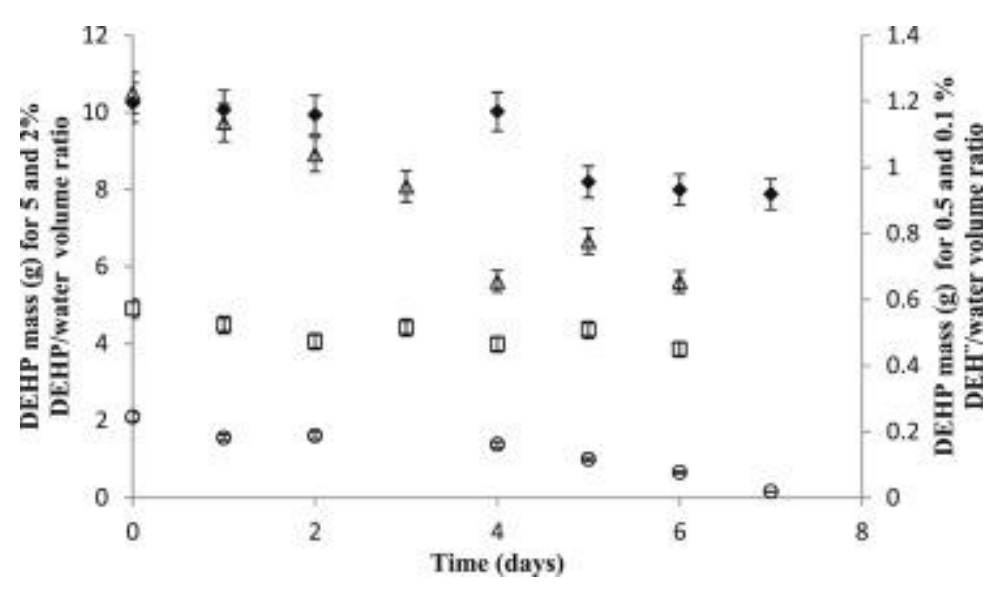

Figure.3. Time-course of DEHP amount during biodegradation by activated sludge in batch culture for an initial toluene concentration in DEHP of $4.3 \mathrm{~g} / \mathrm{L}, \mathrm{pH}=7, \mathrm{~T}=25^{\circ} \mathrm{C}$, stirring rate $=300 \mathrm{rpm} . \quad 5 \% \quad \square 2 \% \quad \triangle 0.5 \% \quad \Delta 0.1 \% \quad \bigcirc 0.1 \%$ glass caps

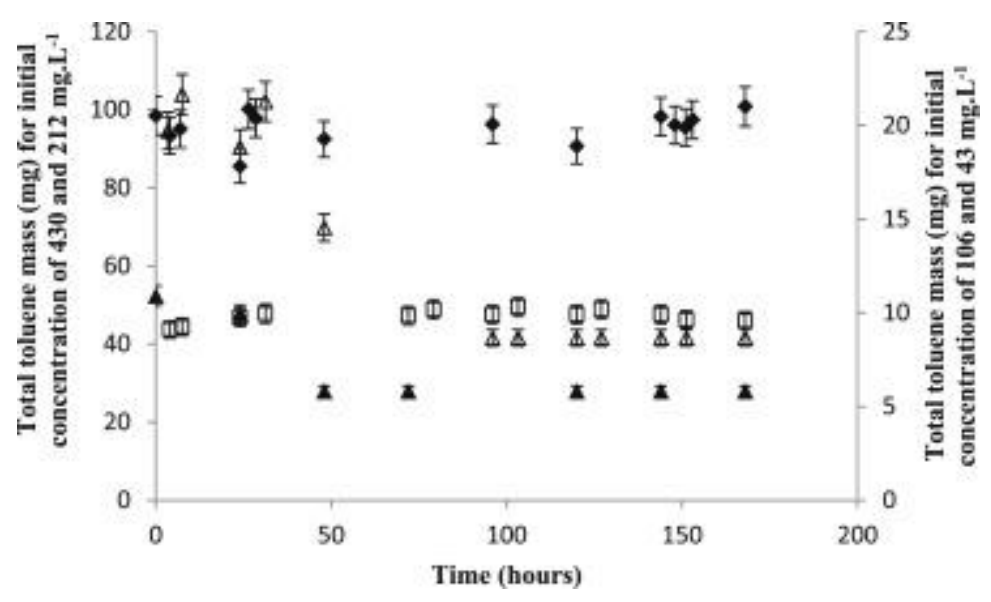

Figure.4. Time-course of toluene total amount during biodegradation by activated sludge in batch culture for a volume ratio DEHP in water of $0.1 \%, p H=7, T=25^{\circ} \mathrm{C}$, stirring rate $=$ 300 rpm. $430 \mathrm{mg} \mathrm{l}^{-1} \quad \square 212 \mathrm{mg} \mathrm{l}^{-1} \quad \triangle 106 \mathrm{mg} \mathrm{l}^{-1} \quad \Delta 43 \mathrm{mg} \mathrm{l}^{-1}$ 


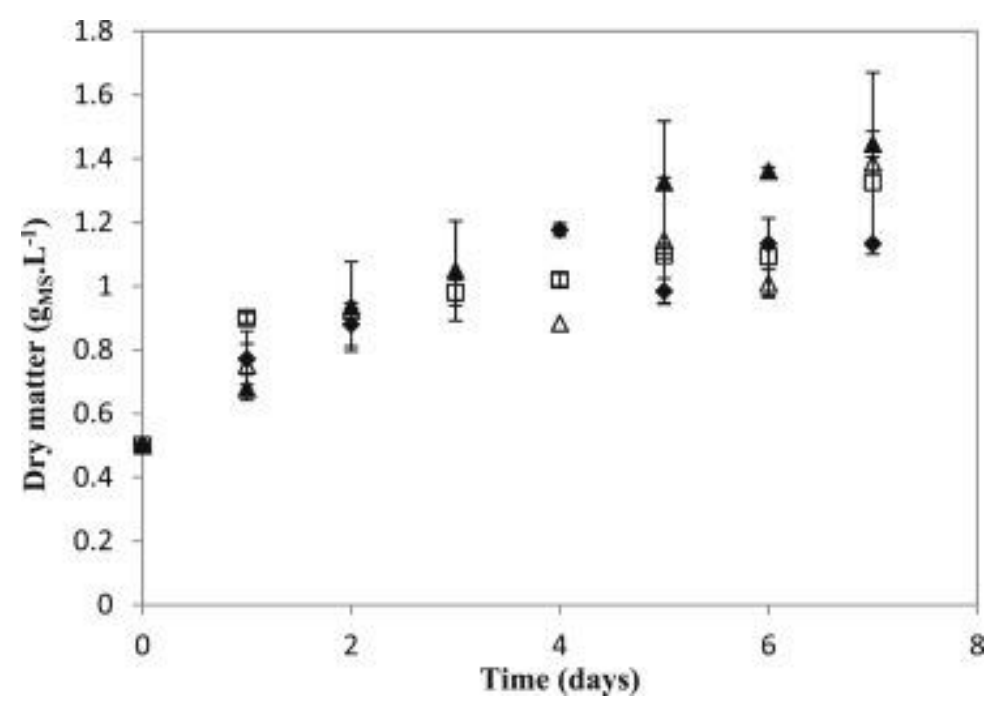

Figure.5. Time-courses of dry matter during biodegradation by activated sludge in batch culture for a volume ratio DEHP in water of $0.1 \%, p H=7, T=25^{\circ} \mathrm{C}$, stirring rate $=300 \mathrm{rpm}$.

• $430 \mathrm{mgl}^{-1} \quad \square 212 \mathrm{mgl}^{-1} \quad \triangle 106 \mathrm{mgl}^{-1} \quad \Delta 43 \mathrm{mgl}^{-1}$

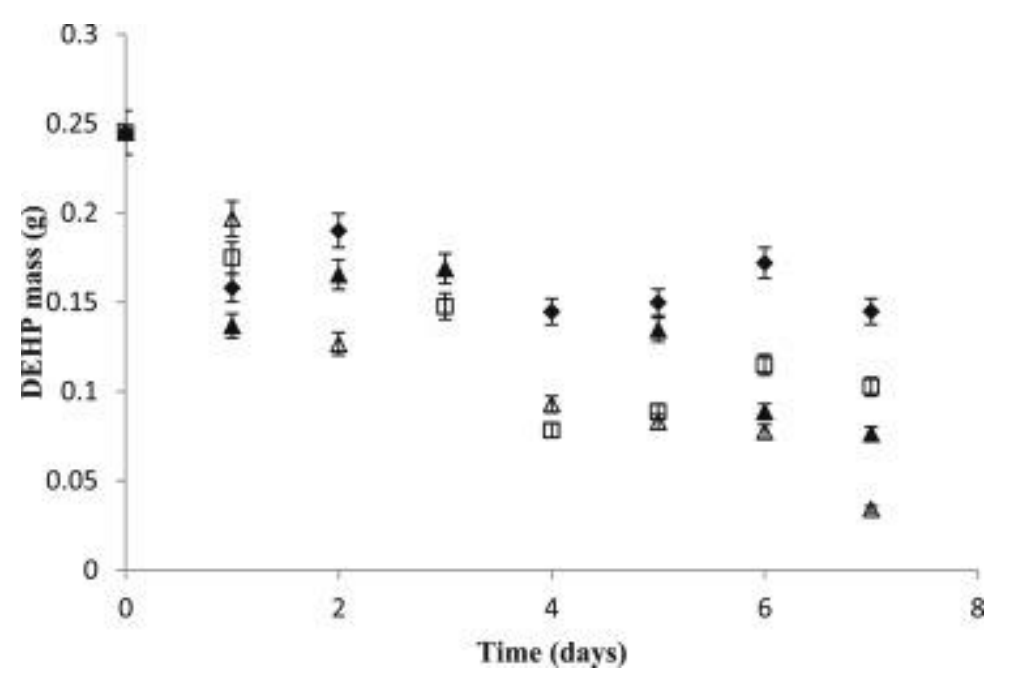

Figure.6. Time-course of DEHP amount during biodegradation by activated sludge in batch culture for a volume ratio DEHP in water of $0.1 \%, \mathrm{pH}=7, \mathrm{~T}=25^{\circ} \mathrm{C}$, stirring rate $=300 \mathrm{rpm}$ - $430 \mathrm{mg} \mathrm{l}^{-1} \quad \square 212 \mathrm{mg} \mathrm{l}^{-1} \quad \triangle 106 \mathrm{mg} \mathrm{l}^{-1} \quad \Delta 43 \mathrm{mg} \mathrm{l}^{-1}$ 
Table 1.

Analytical conditions implemented to determine the amounts of VOC and organic solvent (after line 137).

\begin{tabular}{|c|c|c|c|c|c|c|c|}
\hline Analyte & Apparatus & Column & Detector & $\begin{array}{l}\mathrm{T}_{\text {inj }} \\
\left({ }^{\circ} \mathrm{C}\right)\end{array}$ & $\begin{array}{l}\mathrm{T}_{\text {oven }} \\
\left({ }^{\circ} \mathrm{C}\right)\end{array}$ & $\begin{array}{l}\mathrm{T}_{\text {det }} \\
\left({ }^{\circ} \mathrm{C}\right)\end{array}$ & $\begin{array}{l}\text { Carrier } \\
\text { gas } \\
(\mathrm{ml} \mathrm{min}-1)\end{array}$ \\
\hline $\begin{array}{l}\text { Toluene in } \\
\text { the gas } \\
\text { phase }\end{array}$ & $\begin{array}{l}\text { Thermo } \\
\text { focus GC }\end{array}$ & $\begin{array}{l}\text { CP-FFAP CB; } \\
25 \mathrm{~m}^{\star} 0.32 \mathrm{~mm}\end{array}$ & FID/Split & 200 & 100 & 250 & $\mathrm{~N}_{2}: 3.7$ \\
\hline $\begin{array}{l}\text { Metabolites } \\
\text { in the } \\
\text { aqueous } \\
\text { phase }\end{array}$ & $\begin{array}{l}\text { Perkin Elmer } \\
\text { Clarus } \\
500 \text { GC/MS } \\
\quad .\end{array}$ & $\begin{array}{l}\text { CP-FFAP CB; } \\
30 \mathrm{~m}^{\star} 0.15 \mathrm{~mm}\end{array}$ & MS/HS & 80 & $40-200$ & & $\mathrm{He}: 1$ \\
\hline $\begin{array}{l}\text { DEHP in } \\
\text { hexane }\end{array}$ & Perkin Elmer & $\begin{array}{l}\text { CP-FFAP CB; } \\
25 \mathrm{~m}^{\star} 0.32 \mathrm{~mm}\end{array}$ & FID/Split & 200 & $160-260$ & 250 & $\mathrm{~N}_{2}: 1$ \\
\hline
\end{tabular}

\footnotetext{
Table 2.

Toluene partition coefficient in emulsion of the organic solvent in water (line 180).

\begin{tabular}{l|ll|l|l}
$\begin{array}{l}\text { Solvent } \\
\text { \% in water }\end{array}$ & 5 & 2 & 0.5 & 0.1 \\
\hline $\mathrm{H}$ dimensionless at $25^{\circ} \mathrm{C}$ & 0.0098 & 0.0222 & 0.0816 & 0.1 \\
\hline $\mathrm{H}^{\prime}\left(\mathrm{Pa} \mathrm{m} \mathrm{mole}^{-1}\right)$ at $25^{\circ} \mathrm{C}$ & $24.28 \pm 0.93$ & $55.00 \pm 0.49$ & $202.17 \pm 0.01$ & $247.76 \pm 10.23$ \\
\hline
\end{tabular}
}

